\title{
Cost-Effectiveness of ASHRAE Standard 90.1-2013 for the State of Colorado
}

\section{December 2015}

$\begin{array}{ll}\text { R Hart } & \text { M Halverson } \\ \text { R Athalye } & \text { S Loper } \\ \text { Y Xie } & \text { M Rosenberg } \\ \text { J Zhuge } & \text { E Richman }\end{array}$




\title{
DISCLAIMER
}

This report was prepared as an account of work sponsored by an agency of the United States Government. Neither the United States Government nor any agency thereof, nor Battelle Memorial Institute, nor any of their employees, makes any warranty, express or implied, or assumes any legal liability or responsibility for the accuracy, completeness, or usefulness of any information, apparatus, product, or process disclosed, or represents that its use would not infringe privately owned rights. Reference herein to any specific commercial product, process, or service by trade name, trademark, manufacturer, or otherwise does not necessarily constitute or imply its endorsement, recommendation, or favoring by the United States Government or any agency thereof, or Battelle Memorial Institute. The views and opinions of authors expressed herein do not necessarily state or reflect those of the United States Government or any agency thereof.

\author{
PACIFIC NORTHWEST NATIONAL LABORATORY \\ operated by \\ BATTELLE \\ for the \\ UNITED STATES DEPARTMENT OF ENERGY \\ under Contract DE-AC05-76RL01830
}

Printed in the United States of America
Available to DOE and DOE contractors from the Office of Scientific and Technical Information, P.O. Box 62, Oak Ridge, TN 37831-0062; ph: (865) 576-8401 fax: $(865) 576-5728$
email: reports $a$ adonis.osti.gov
Available to the public from the National Technical Information Service 5301 Shawnee Rd., Alexandria, VA 22312 ph: (800) 553-NTIS (6847) email: orders@ntis.gov <http://www.ntis.gov/about/form.aspx> Online ordering: http://www.ntis.gov




\title{
Cost-Effectiveness of ASHRAE Standard 90.1-2013 for the State of Colorado
}

\author{
R Hart \\ M Halverson \\ R Athalye \\ S Loper \\ Y Xie \\ M Rosenberg \\ J Zhuge \\ E Richman
}

December 2015

Prepared for

the U.S. Department of Energy

under Contract DE-AC05-76RL01830

Pacific Northwest National Laboratory

Richland, Washington 99352 

PNNL-25012

\section{Acronyms and Abbreviations}

ASHRAE

BECP

BTO

DOE

EIA

FEMP

HVAC

LCC

NIST

PNNL

UPV

SWH
American Society of Heating, Refrigerating and Air-Conditioning Engineers

Building Energy Codes Program

Building Technologies Office

U.S. Department of Energy

Energy Information Administration

Federal Energy Management Program

Heating, Ventilating, and Air-Conditioning

Life-Cycle Cost

National Institute of Standards and Technology

Pacific Northwest National Laboratory

Uniform Present Value

Service Water Heating 


\section{Highlights}

Moving to the ASHRAE Standard 90.1-2013 (ASHRAE 2013) edition from Standard 90.1-2010 (ASHRAE 2010) is cost-effective for the State of Colorado. The table below shows the state-wide economic impact of upgrading to Standard 90.1-2013 in terms of the annual energy cost savings in dollars per square foot, additional construction cost per square foot required by the upgrade, and life-cycle cost (LCC) per square foot. These results are weighted averages for all building types in all climate zones in the state, based on weightings shown in Table 4. The methodology used for this analysis is consistent with the methodology used in the national cost-effectiveness analysis ${ }^{1}$. Additional results and details on the methodology are presented in the following sections.

\begin{tabular}{lc}
\hline \multicolumn{2}{c}{$\begin{array}{c}\text { Average Savings, Construction Cost and LCC } \\
\text { (Weighted by Climate Zone and Building Type) }\end{array}$} \\
\hline Annual Cost Savings, $\$ / \mathrm{ft}^{2}$ & $\$ 0.107$ \\
Added Construction Cost, $\$ / \mathrm{ft}^{2}$ & $\$ 0.293$ \\
Publicly-owned scenario LCC Savings, $\$ / \mathrm{ft}^{2}$ & $\$ 1.63$ \\
Privately-owned scenario LCC Savings, $\$ / \mathrm{ft}^{2}$ & $\$ 1.43$ \\
\hline
\end{tabular}

The report provides analysis of two LCC scenarios:

- Scenario 1, representing publicly-owned buildings, considers initial costs, energy costs, maintenance costs, and replacement costs-without borrowing or taxes.

- Scenario 2, representing privately-owned buildings, adds borrowing costs and tax impacts.

Figure 1 compares annual energy cost savings, first cost for the upgrade, and net annualized LCC savings. The net annualized LCC savings per square foot is the annual energy savings net of an allowance to pay for the added cost under scenario 1. Figure 2 shows overall state weighted net LCC results for both scenarios. When net LCC is positive, the updated code edition is considered cost-effective.

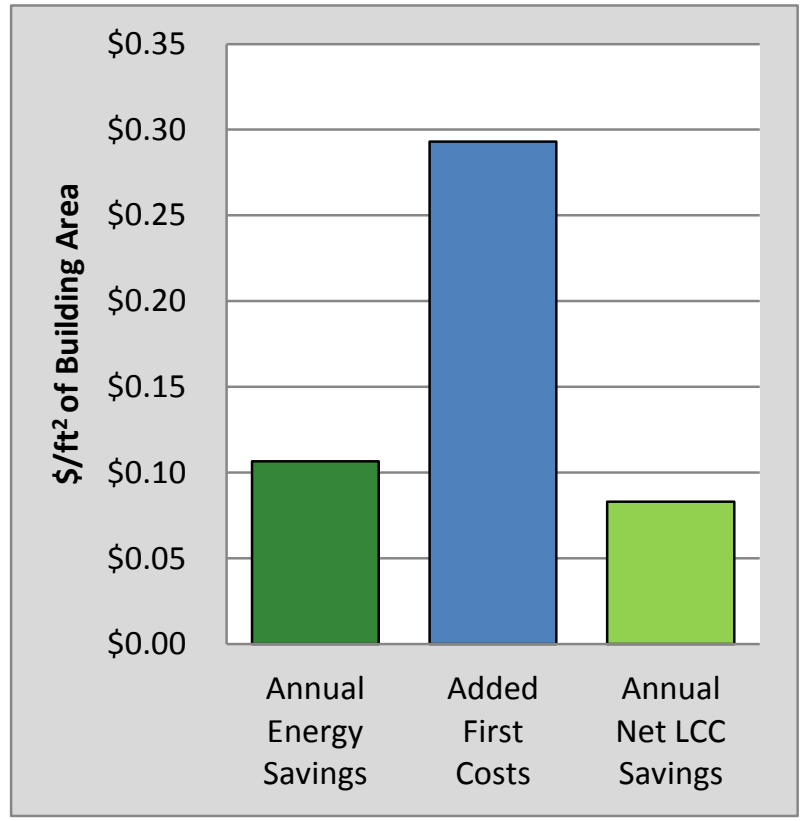

Figure 1. State-wide Weighted Costs and Savings

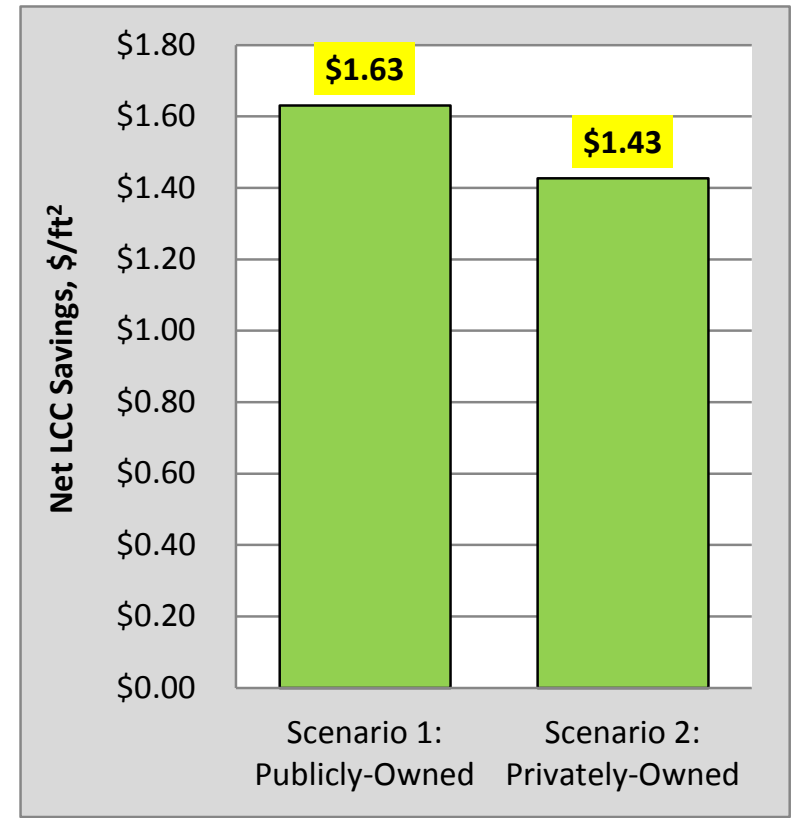

Figure 2. Overall Net Life-Cycle Cost Savings

\footnotetext{
${ }^{1}$ National cost-effectiveness report: https://www.energycodes.gov/development/commercial/cost_effectiveness.
} 


\section{Cost-Effectiveness Results for ASHRAE Standard 90.1-2013 in Colorado}

This section summarizes the cost-effectiveness analysis results. Life-Cycle Cost (LCC) savings is the primary measure DOE uses to assess the economic impact of building energy codes. Savings are computed for two scenarios:

- Scenario 1 (publicly-owned) includes costs for initial equipment and construction, energy, maintenance and replacement and does not include loans or taxes.

- Scenario 2 (privately-owned) includes the same costs as scenario 1, plus the initial investment is financed through a loan amortized over 30 years with corresponding federal and state corporate income tax deductions for interest and depreciation.

Both scenarios include the residual value of equipment with remaining useful life at the end of the 30 years. Totals for building types, climate zones, and the state overall are averages based on Table 4 weightings. Factors such as inflation and discount rates are different between the two scenarios, as described in the Cost-Effectiveness Methodology section.

LCC is affected by many variables, including the applicability of individual measures in the code, measure costs, measure lives, replacement costs, state cost adjustment, energy prices, and so on. The LCC could be negative for a building type in a climate zone based on the interaction of these variables, but the code is considered cost-effective as long as the weighted state-wide LCC is positive.

Table 1 shows that the value today of the total LCC savings over 30 years for buildings in scenario 1 averages $\$ 1.63$ per square foot for Standard 90.1-2013.

Table 1. LCC Savings for Colorado, Scenario $1\left(\$ / \mathrm{ft}^{2}\right)$

\begin{tabular}{|cccccccc|}
\hline Climate Zone & Small Office & Large Office & $\begin{array}{c}\text { Stand-Alone } \\
\text { Retail }\end{array}$ & $\begin{array}{c}\text { Primary } \\
\text { School }\end{array}$ & Small Hotel & $\begin{array}{c}\text { Mid-Rise } \\
\text { Apartment }\end{array}$ & $\begin{array}{c}\text { All Building } \\
\text { Types }\end{array}$ \\
\hline 4B & $\$ 0.66$ & $\$ 30.07$ & $\$ 2.15$ & $\$ 4.23$ & $\$ 1.57$ & $\$ 0.79$ & $\$ 2.03$ \\
\hline 5B & $\$ 0.96$ & $\$ 2.21$ & $\$ 1.94$ & $\$ 4.06$ & $\$ 1.36$ & $\$ 0.58$ & $\$ 1.72$ \\
\hline $6 B$ & $\$ 1.47$ & $\$ 0.08$ & $\$ 2.55$ & $\$ 0.58$ & $\$ 1.35$ & $\$ 0.41$ & $\$ 0.89$ \\
\hline 7 & $\$ 0.76$ & $\$ 1.79)$ & $\$ 1.38$ & $\$ 0.21$ & $\$ 1.42$ & $\$ 0.02$ & $\$ 0.37$ \\
\hline State Average & $\$ 0.96$ & $\$ 2.21$ & $\$ 1.94$ & $\$ 3.88$ & $\$ 1.37$ & $\$ 0.51$ & $\$ 1.63$ \\
\hline
\end{tabular}

Table 2 shows that the LCC savings over 30 years averages $\$ 1.43$ per square foot for scenario 2 .

Table 2. LCC Savings for Colorado, Scenario $2\left(\$ / \mathrm{ft}^{2}\right)$

\begin{tabular}{|cccccccc|}
\hline Climate Zone & Small Office & Large Office & $\begin{array}{c}\text { Stand-Alone } \\
\text { Retail }\end{array}$ & $\begin{array}{c}\text { Primary } \\
\text { School }\end{array}$ & Small Hotel & $\begin{array}{c}\text { Mid-Rise } \\
\text { Apartment }\end{array}$ & $\begin{array}{c}\text { All Building } \\
\text { Types }\end{array}$ \\
\hline 4B & $\$ 1.09$ & $\$ 19.27$ & $\$ 1.61$ & $\$ 3.88$ & $\$ 1.51$ & $\$ 0.76$ & $\$ 1.89$ \\
\hline 5B & $\$ 1.19$ & $\$ 1.86$ & $\$ 1.43$ & $\$ 3.75$ & $\$ 1.37$ & $\$ 0.65$ & $\$ 1.49$ \\
\hline 6B & $\$ 1.41$ & $\$ 0.23$ & $\$ 1.85$ & $\$ 0.93$ & $\$ 1.37$ & $\$ 0.56$ & $\$ 0.89$ \\
\hline 7 & $\$ 0.96$ & $\$ 0.97)$ & $\$ 1.13$ & $\$ 0.71$ & $\$ 1.45$ & $\$ 0.23$ & $\$ 0.51$ \\
\hline State Average & $\$ 1.19$ & $\$ 1.86$ & $\$ 1.43$ & $\$ 3.61$ & $\$ 1.37$ & $\$ 0.60$ & $\$ 1.43$ \\
\hline
\end{tabular}




\section{Energy Cost Savings}

Table 3 shows that the primary benefit of Standard 90.1-2013 — annual energy cost savings - averages $\$ 0.107$ per square foot for both scenarios.

Table 3. Annual Energy Cost Savings for Colorado $\left(\$ / \mathrm{ft}^{2}\right)$

\begin{tabular}{|cccccccc|}
\hline Climate Zone & Small Office & Large Office & $\begin{array}{c}\text { Stand-Alone } \\
\text { Retail }\end{array}$ & $\begin{array}{c}\text { Primary } \\
\text { School }\end{array}$ & Small Hotel & $\begin{array}{c}\text { Mid-Rise } \\
\text { Apartment }\end{array}$ & $\begin{array}{c}\text { All Building } \\
\text { Types }\end{array}$ \\
\hline 4B & $\$ 0.101$ & $\$ 0.063$ & $\$ 0.149$ & $\$ 0.195$ & $\$ 0.102$ & $\$ 0.050$ & $\$ 0.123$ \\
\hline 5B & $\$ 0.089$ & $\$ 0.055$ & $\$ 0.138$ & $\$ 0.191$ & $\$ 0.106$ & $\$ 0.052$ & $\$ 0.109$ \\
\hline 6B & $\$ 0.079$ & $\$ 0.032$ & $\$ 0.148$ & $\$ 0.124$ & $\$ 0.108$ & $\$ 0.053$ & $\$ 0.077$ \\
\hline 7 & $\$ 0.078$ & $\$ 0.024$ & $\$ 0.191$ & $\$ 0.120$ & $\$ 0.115$ & $\$ 0.034$ & $\$ 0.076$ \\
\hline State Average & $\$ 0.089$ & $\$ 0.055$ & $\$ 0.139$ & $\$ 0.188$ & $\$ 0.106$ & $\$ 0.050$ & $\$ 0.107$ \\
\hline
\end{tabular}

\section{Construction Weighting of Results}

Energy and economic impacts were determined and reported separately for each building type and climate zone. Cost-effectiveness results are also reported as averages for all prototypes and climate zones in the state. To determine these averages, results were combined across the different building types and climate zones using weighting factors shown in Table 4 . These weighting factors are based on the floor area of new construction and major renovations for the six analyzed building prototypes in state-specific climate zones. The weighting factors were developed from construction start data from 2003 to 2007 based on an approach developed by Jarnagin and Bandyopadhyay (McGraw Hill Construction 2007, Jarnagin and Bandyopadhyay 2010).

Table 4. Construction Weights by Building Type

\begin{tabular}{|cccccccc|c|}
\hline Climate Zone & $\begin{array}{c}\text { Small } \\
\text { Office }\end{array}$ & $\begin{array}{c}\text { Large } \\
\text { Office }\end{array}$ & $\begin{array}{c}\text { Stand-Alone } \\
\text { Retail }\end{array}$ & $\begin{array}{c}\text { Primary } \\
\text { School }\end{array}$ & $\begin{array}{c}\text { Small } \\
\text { Hotel }\end{array}$ & $\begin{array}{c}\text { Mid-Rise } \\
\text { Apartment }\end{array}$ & $\begin{array}{c}\text { All Building } \\
\text { Types }\end{array}$ \\
\hline 4B & $0.0 \%$ & $0.0 \%$ & $0.0 \%$ & $0.0 \%$ & $0.1 \%$ & $0.0 \%$ & $0.1 \%$ \\
\hline 5B & $12.8 \%$ & $7.9 \%$ & $38.6 \%$ & $9.0 \%$ & $3.2 \%$ & $20.0 \%$ & $91.6 \%$ \\
\hline 6B & $0.1 \%$ & $0.0 \%$ & $0.8 \%$ & $0.2 \%$ & $0.3 \%$ & $3.1 \%$ & $4.5 \%$ \\
\hline 7 & $0.2 \%$ & $0.0 \%$ & $0.7 \%$ & $0.3 \%$ & $0.1 \%$ & $2.4 \%$ & $3.7 \%$ \\
\hline State Average & $13.2 \%$ & $7.9 \%$ & $40.2 \%$ & $9.5 \%$ & $3.7 \%$ & $25.5 \%$ & $100.0 \%$ \\
\hline
\end{tabular}

\section{Incremental Construction Cost}

Cost estimates were developed for the differences between Standard 90.1-2010 and Standard 90.1-2013 as implemented in the six prototype models. Costs for the initial construction include material, labor, commissioning, construction equipment, overhead and profit. These costs were developed using a commercial cost estimation firm, engineering design consultants and RS Means 2012 and 2014 cost data (RS Means 2012a,b,c, 2014a,b,c; Hart et al. 2015). The costs were developed at the national level and then adjusted for local conditions using a state construction cost index (Means 2014c). Table 5 shows incremental initial cost for individual building types in state-specific climate zones and weighted average costs by climate zone and building type for moving to Standard 90.1-2013 from Standard 90.1-2010.

The incremental cost is negative for some building types and climate zones because of fewer lighting fixtures, or due to the downsizing of heating, ventilating, and air-conditioning (HVAC) equipment.

- Fewer light fixtures are required when the allowed lighting power is reduced. 
- Smaller equipment sizes can result from the lowering of heating and cooling loads due to other efficiency measures, such as more wall insulation.

The national cost-effectiveness report contains detailed descriptions of how costs were developed for individual efficiency upgrades (Hart et al. 2015). Where cost is negative it represents a reduction in first costs and a savings that is included in the net LCC savings.

Table 5. Incremental Construction Cost for Colorado $\left(\$ / \mathrm{ft}^{2}\right)$

\begin{tabular}{|cccccccc|}
\hline Climate Zone & Small Office & Large Office & $\begin{array}{c}\text { Stand-Alone } \\
\text { Retail }\end{array}$ & $\begin{array}{c}\text { Primary } \\
\text { School }\end{array}$ & Small Hotel & $\begin{array}{c}\text { Mid-Rise } \\
\text { Apartment }\end{array}$ & $\begin{array}{c}\text { All Building } \\
\text { Types }\end{array}$ \\
\hline 4B & $\$ 2.149$ & $(\$ 28.045)$ & $(\$ 0.413)$ & $\$ 0.834$ & $\$ 0.685$ & $\$ 0.354$ & $\$ 0.662$ \\
\hline 5B & $\$ 1.484$ & $(\$ 0.372)$ & $(\$ 0.438)$ & $\$ 0.906$ & $\$ 0.875$ & $\$ 0.636$ & $\$ 0.250$ \\
\hline $6 B$ & $\$ 0.556$ & $\$ 0.676$ & $(\$ 0.885)$ & $\$ 1.960$ & $\$ 0.938$ & $\$ 0.873$ & $\$ 0.598$ \\
\hline 7 & $\$ 1.260$ & $\$ 2.379$ & $\$ 0.605$ & $\$ 2.335$ & $\$ 1.011$ & $\$ 0.886$ & $\$ 0.968$ \\
\hline State Average & $\$ 1.473$ & $(\$ 0.372)$ & $(\$ 0.428)$ & $\$ 0.969$ & $\$ 0.878$ & $\$ 0.689$ & $\$ 0.293$ \\
\hline
\end{tabular}

\section{Simple Payback}

Simple payback is the total incremental first cost divided by the annual savings, where the annual savings is the annual energy cost savings less any incremental annual maintenance cost. Simple payback is not used as a measure of cost-effectiveness as it does not account for the time value of money, the value of energy cost savings that occur after payback is achieved, or any replacement costs that occur after the initial investment. However, it is included in the analysis for states who wish to use this information. Table 6 shows simple payback results in years for both scenarios.

Table 6. Simple Payback for Colorado (Years)

\begin{tabular}{|ccccccccc|}
\hline Climate Zone & $\begin{array}{c}\text { Small } \\
\text { Office }\end{array}$ & $\begin{array}{c}\text { Large } \\
\text { Office }\end{array}$ & $\begin{array}{c}\text { Stand-Alone } \\
\text { Retail }\end{array}$ & $\begin{array}{c}\text { Primary } \\
\text { School }\end{array}$ & $\begin{array}{c}\text { Small } \\
\text { Hotel }\end{array}$ & $\begin{array}{c}\text { Mid-Rise } \\
\text { Apartment }\end{array}$ & $\begin{array}{c}\text { All Building } \\
\text { Types }\end{array}$ \\
\hline 4B & 21.3 & Immediate & Immediate & 4.1 & 6.4 & 6.9 & 6.1 \\
\hline 5B & 16.6 & Immediate & Immediate & 4.4 & 8.1 & 11.7 & 5.6 \\
\hline 6B & 7.1 & 23.6 & Immediate & 15.5 & 8.5 & 15.8 & 12.2 \\
\hline 7 & 16.2 & 114.5 & 3.3 & 19.1 & 8.7 & 24.8 & 19.3 \\
\hline State Average & 16.5 & Immediate & Immediate & 5.1 & 8.1 & 13.4 & 6.4 \\
\hline
\end{tabular}




\section{Overview of the Cost-Effectiveness Methodology}

This analysis was conducted by Pacific Northwest National Laboratory (PNNL) in support of the U.S. Department of Energy's (DOE) Building Energy Codes Program. DOE supports the development and implementation of energy efficient and cost-effective residential and commercial building energy codes. These codes help adopting states and localities establish minimum requirements for energy-efficient building design and construction, as well as ensure significant energy savings and avoided greenhouse gas emissions. LCC savings is the primary measure DOE uses to assess the cost-effectiveness of building energy codes.

\section{Cost-Effectiveness}

DOE uses standard economic LCC cost-effectiveness analysis methods in comparing Standard 90.1-2013 and Standard 90.1-2010. A detailed cost-effectiveness methodology was used as described in detail in the national report (Hart et al. 2015). Under this methodology, two metrics are used:

- LCC Savings: LCC is the calculation of the present value of costs over a 30-year period including initial equipment and construction costs, energy savings, maintenance and replacement costs, and residual value of components at the end of the 30-year period. A separate LCC is determined for Standard 90.1-2010 and for Standard 90.1-2013. The LCC savings is the Standard 90.1-2010 LCC minus the Standard 90.1-2013 LCC.

- Simple Payback: While not a true cost-effectiveness metric, simple payback is also calculated. Simple payback is the number of years required for accumulated annual energy cost savings to exceed the incremental first costs of a new code.

Two cost scenarios are analyzed:

- Scenario 1 includes the costs and savings listed above without borrowing or tax impacts.

- Scenario 2 incudes the same costs as scenario 1 plus financing of the incremental first costs through increased borrowing with tax impacts including mortgage interest and depreciation deductions. Corporate tax rates are applied. Economic analysis factors such as discount rates are also different, as described in Table 8.

The cost-effectiveness analysis compares the cost for new buildings meeting Standard 90.1-2013 compared to new buildings meeting Standard 90.1-2010. The analysis includes energy savings estimates from building energy simulations and LCC and simple payback calculations using standard economic analysis parameters. The analysis builds on work documented in ANSI/ASHRAE/IES Standard 90.1-2013 Determination of Energy Savings: Quantitative Analysis (Halverson et al. 2014), and the costeffectiveness analysis documented in National Cost-effectiveness of ANSI/ASHRAE/IES Standard 90.1 2013 (Hart et al. 2015).

\section{Building Prototypes and Energy Modeling}

The cost-effectiveness analysis uses six building types represented by six prototype building energy models. These six are a subset of 16 prototype building energy models and represent $80 \%$ of commercial floor space. These models provide coverage of the significant changes in ASHRAE Standard 90.1 from 2010 to 2013 and are used to show the impacts of the changes on energy savings. The prototypes represent common construction practice and include the primary conventional HVAC systems most commonly used in commercial buildings. More information on the prototype buildings and savings analysis can be found at: www.energycodes.gov/development/commercial/90.1_models. 
Each prototype building is analyzed for each of the climate zones found within the state. Using the U.S. DOE EnergyPlus ${ }^{\mathrm{TM}}$ software, the six building prototypes summarized in Table 7 are simulated with characteristics meeting the requirements of Standard 90.1-2010 and then modified to meet the requirements of the next edition of the code (Standard 90.1-2013). The energy use and cost are then compared between the two sets of models.

Table 7. Building Prototypes

\begin{tabular}{ccc}
\hline Building Prototype & Floor Area $\left(\mathrm{ft}^{2}\right)$ & Number of Floors \\
\hline Small Office & 5,500 & 1 \\
Large Office & 498,640 & 13 \\
Stand-Alone Retail & 24,690 & 1 \\
Primary School & 73,970 & 1 \\
Small Hotel & 43,210 & 4 \\
Mid-Rise Apartment & 33,740 & 4 \\
\hline
\end{tabular}

\section{Climate Zones}

Climate zones are defined in ASHRAE Standard 90.1 and include eight primary climate zones, the hottest being climate zone 1 and the coldest being climate zone 8 . Letters $\mathrm{A}, \mathrm{B}$, and $\mathrm{C}$ are applied in some cases to denote the level of moisture, with A indicating moist or humid, B indicating dry, and C indicating marine. Figure 3 shows the national climate zones. For this state analysis, savings are analyzed for each climate zone in the state using weather data from a selected city within the climate zone and state, or where necessary, a city in an adjoining state with more robust weather data.

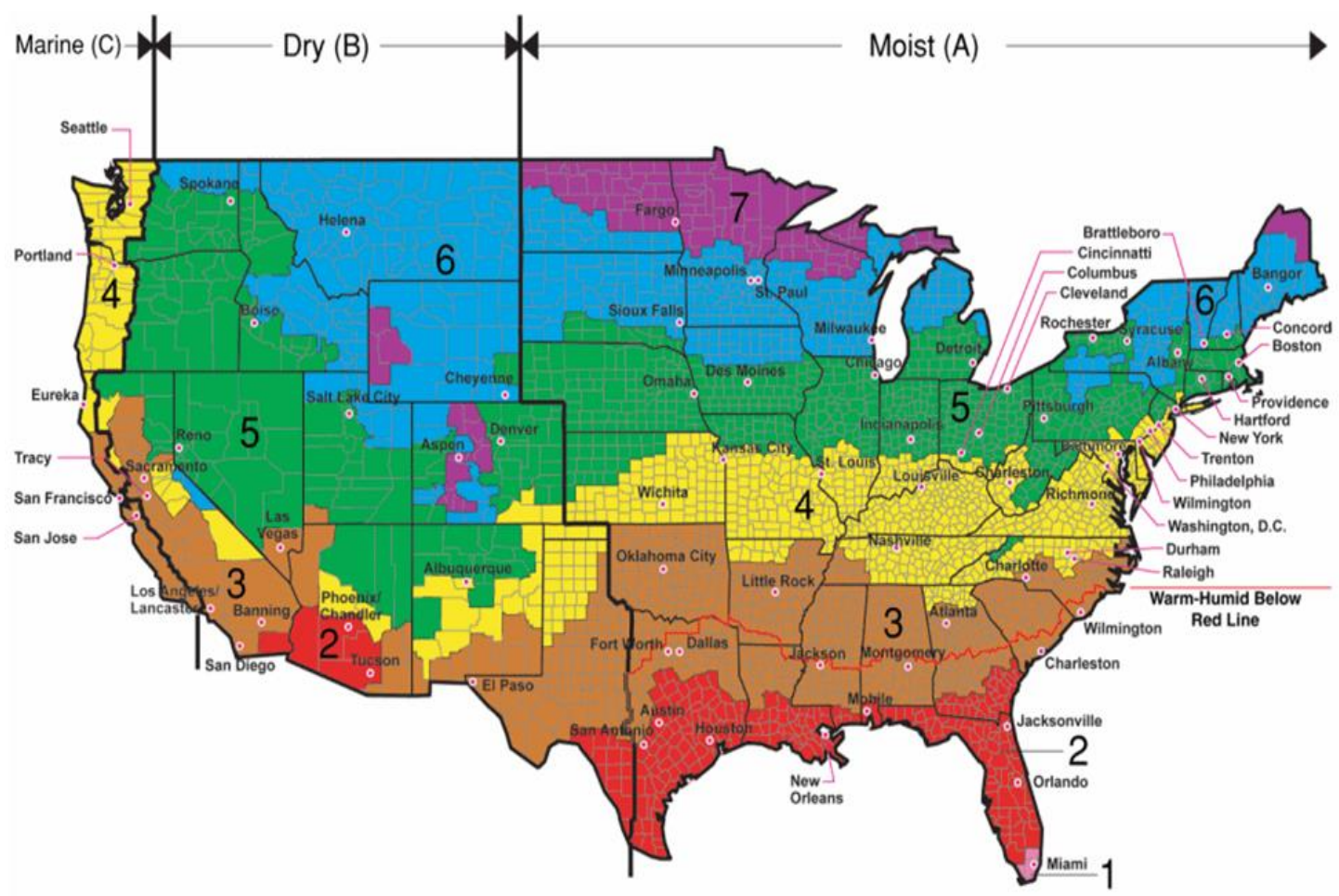

All of Alaska in Zone 7 except for the following Boroughs in Zone 8: Bethel, Dellingham, Fairbanks, N. Star, Nome North Slope, Northwest Arctic, Southeast Fairbanks, Wade Hampton, and Zone 1 includes: Hawail, Guam, Puerto Rico, and the Virgin Islands

Figure 3. National Climate Zones 


\section{Cost-Effectiveness Method and Parameters}

The DOE cost-effectiveness methodology accounts for the benefits of energy-efficient building construction over a multi-year analysis period, balancing initial costs against longer term energy savings. DOE evaluates energy codes and code proposals based on LCC analysis over a multi-year study period, accounting for energy savings, incremental investment for energy efficiency measures, and other economic impacts. The value of future savings and costs are discounted to a present value, with improvements deemed cost-effective when the net LCC savings (present value of savings minus cost) is positive.

The U.S. DOE Building Energy Codes Program uses an LCC analysis similar to the method used for many federal building projects, as well as other public and private building projects (Fuller and Petersen 1995). The LCC analysis method consists of identifying costs (and revenues if any) and in what year they occur; then determining their value in today's dollars (known as the present value). This method uses economic relationships about the time value of money (money today is normally worth more than money tomorrow, which is why we pay interest on a loan and earn interest on savings). Future costs are discounted to the present based on a discount rate. The discount rate may reflect the interest rate at which money can be borrowed for projects with the same level of risk or the interest rate that can be earned on other conventional investments with similar risk.

The LCC for both scenarios includes incremental initial costs, repairs, maintenance and replacements. Scenario 2 also includes loan costs and tax impacts including mortgage interest and depreciation deductions. The residual value of equipment (or other component such as roof membrane) that has remaining useful life at end of the 30-year study period is also included for both scenarios. The residual value is calculated by multiplying the initial cost of the component by the years of useful life remaining for the component at year 30 divided by the total useful life, a simplified approach included in the Federal Energy Management Program (FEMP) LCC method (Fuller and Petersen 1995). A component will have zero residual value at year 30 only if it has a 30 -year life, or if it has a shorter than 30-year life that divides exactly into 30 years (for example, a 15-year life).

The financial and economic parameters used for the LCC calculations are shown in Table 8 . 
PNNL-25012

Table 8. LCC Economic Parameters

\begin{tabular}{|c|c|c|}
\hline Economic Parameter & Scenario 1 & Scenario 2 \\
\hline Study Period - Years ${ }^{1}$ & 30 & 30 \\
\hline Nominal Discount Rate ${ }^{2}$ & $3.10 \%$ & $5.50 \%$ \\
\hline Real Discount Rate ${ }^{2}$ & $3.00 \%$ & $3.53 \%$ \\
\hline Effective Inflation Rate ${ }^{3}$ & $0.10 \%$ & $1.90 \%$ \\
\hline Electricity Prices ${ }^{4}$ (per kWh) & $\$ 0.1020$ & $\$ 0.1020$ \\
\hline Natural Gas Prices ${ }^{4}$ (per therm) & $\$ 0.7897$ & $\$ 0.7897$ \\
\hline Energy Price Escalation Factors ${ }^{5}$ & Uniform present value factors & Uniform present value factors \\
\hline Electricity Price UPV ${ }^{5}$ & 20.68 & 17.71 \\
\hline Natural Gas Price UPV ${ }^{5}$ & 23.60 & 20.21 \\
\hline Loan Interest Rate ${ }^{6}$ & NA & $5.50 \%$ \\
\hline Federal Corporate Tax Rate ${ }^{7}$ & NA & $34.00 \%$ \\
\hline State Corporate Tax Rate ${ }^{8}$ & NA & $4.63 \%$ \\
\hline Combined Income Tax Impact ${ }^{9}$ & NA & $37.06 \%$ \\
\hline State and Average Local Sales Tax ${ }^{10}$ & $7.39 \%$ & $7.39 \%$ \\
\hline State Construction Cost Index ${ }^{11}$ & 0.922 & 0.922 \\
\hline \multicolumn{3}{|c|}{ 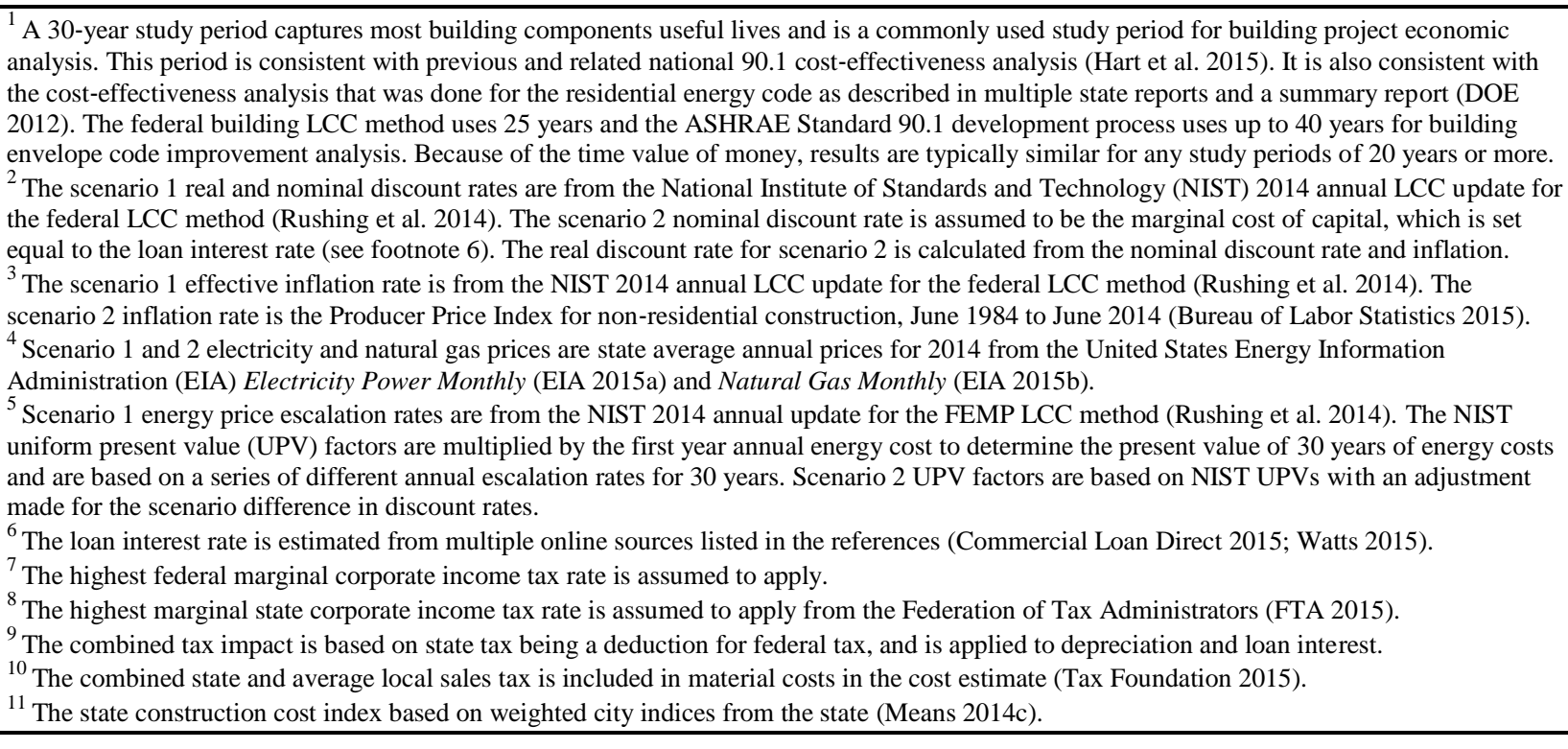 } \\
\hline
\end{tabular}




\section{Detailed Energy Use and Cost}

On the following pages, specific detailed results for Colorado are included:

- Table 9 shows the average energy rates used.

- Tables 10.A and 10.B show the per square foot energy costs for Standard 90.1-2010 and Standard 90.1-2013 and the cost savings from Standard 90.1-2013.

- Tables 11.A and 11.B show the per square foot energy use for Standard 90.1-2010 and Standard 90.12013 and the energy use savings from Standard 90.1-2013.

- Tables 12.A through 12.D show the energy end use by energy type for each climate zone in the state.

Table 9. Energy Rates for Colorado, Average \$ per unit

\begin{tabular}{ccc}
\hline Electricity & $\$ 0.1020$ & $\mathrm{kWh}$ \\
Gas & $\$ 0.7897$ & Therm \\
\hline
\end{tabular}

Source: Energy Information Administration, annual average prices for 2014 (EIA

2015a,b) 
Table 10.A. Energy Cost Saving Results in Colorado, \$ per Square Foot

\begin{tabular}{|c|c|c|c|c|c|c|c|c|c|c|c|c|}
\hline \multirow{2}{*}{$\begin{array}{l}\text { Climate Zone: } \\
\text { Code: }\end{array}$} & \multicolumn{4}{|c|}{$4 \mathrm{~B}$} & \multicolumn{4}{|c|}{$5 \mathrm{~B}$} & \multicolumn{4}{|c|}{$6 \mathrm{~B}$} \\
\hline & $90.1-2010$ & $90.1-2013$ & \multicolumn{2}{|l|}{ Savings } & $90.1-2010$ & $90.1-2013$ & \multicolumn{2}{|l|}{ Savings } & $90.1-2010$ & $90.1-2013$ & \multicolumn{2}{|l|}{ Savings } \\
\hline \multicolumn{13}{|l|}{ Small Office } \\
\hline Electricity & $\$ 0.960$ & $\$ 0.861$ & $\$ 0.100$ & $10.4 \%$ & $\$ 0.936$ & $\$ 0.848$ & $\$ 0.088$ & $9.4 \%$ & $\$ 0.917$ & $\$ 0.839$ & $\$ 0.078$ & $8.5 \%$ \\
\hline Gas & $\$ 0.004$ & $\$ 0.003$ & $\$ 0.001$ & $25.0 \%$ & $\$ 0.004$ & $\$ 0.003$ & $\$ 0.001$ & $25.0 \%$ & $\$ 0.010$ & $\$ 0.009$ & $\$ 0.001$ & $10.0 \%$ \\
\hline Totals & $\$ 0.965$ & $\$ 0.864$ & $\$ 0.101$ & $10.5 \%$ & $\$ 0.940$ & $\$ 0.851$ & $\$ 0.089$ & $9.5 \%$ & $\$ 0.927$ & $\$ 0.848$ & $\$ 0.079$ & $8.5 \%$ \\
\hline \multicolumn{13}{|l|}{ Large Office } \\
\hline Electricity & $\$ 2.031$ & $\$ 1.973$ & $\$ 0.057$ & $2.8 \%$ & $\$ 1.994$ & $\$ 1.946$ & $\$ 0.048$ & $2.4 \%$ & $\$ 1.979$ & $\$ 1.942$ & $\$ 0.037$ & $1.9 \%$ \\
\hline Gas & $\$ 0.039$ & $\$ 0.033$ & $\$ 0.006$ & $15.4 \%$ & $\$ 0.044$ & $\$ 0.037$ & $\$ 0.007$ & $15.9 \%$ & $\$ 0.061$ & $\$ 0.067$ & $-\$ 0.005$ & $-8.2 \%$ \\
\hline Totals & $\$ 2.069$ & $\$ 2.006$ & $\$ 0.063$ & $3.0 \%$ & $\$ 2.037$ & $\$ 1.983$ & $\$ 0.055$ & $2.7 \%$ & $\$ 2.041$ & $\$ 2.009$ & $\$ 0.032$ & $1.6 \%$ \\
\hline \multicolumn{13}{|c|}{ Stand-Alone Retail } \\
\hline Electricity & $\$ 1.236$ & $\$ 1.102$ & $\$ 0.134$ & $10.8 \%$ & $\$ 1.203$ & $\$ 1.087$ & $\$ 0.116$ & $9.6 \%$ & $\$ 1.191$ & $\$ 1.060$ & $\$ 0.131$ & $11.0 \%$ \\
\hline Gas & $\$ 0.108$ & $\$ 0.092$ & $\$ 0.016$ & $14.8 \%$ & $\$ 0.123$ & $\$ 0.101$ & $\$ 0.022$ & $17.9 \%$ & $\$ 0.152$ & $\$ 0.135$ & $\$ 0.017$ & $11.2 \%$ \\
\hline Totals & $\$ 1.344$ & $\$ 1.194$ & $\$ 0.149$ & $11.1 \%$ & $\$ 1.326$ & $\$ 1.188$ & $\$ 0.138$ & $10.4 \%$ & $\$ 1.343$ & $\$ 1.195$ & $\$ 0.148$ & $11.0 \%$ \\
\hline \multicolumn{13}{|c|}{ Primary School } \\
\hline Electricity & $\$ 1.210$ & $\$ 0.988$ & $\$ 0.222$ & $18.3 \%$ & $\$ 1.176$ & $\$ 0.954$ & $\$ 0.222$ & $18.9 \%$ & $\$ 1.142$ & $\$ 1.026$ & $\$ 0.117$ & $10.2 \%$ \\
\hline Gas & $\$ 0.111$ & $\$ 0.137$ & $-\$ 0.026$ & $-23.4 \%$ & $\$ 0.117$ & $\$ 0.148$ & $-\$ 0.031$ & $-26.5 \%$ & $\$ 0.143$ & $\$ 0.136$ & $\$ 0.007$ & $4.9 \%$ \\
\hline Totals & $\$ 1.321$ & $\$ 1.125$ & $\$ 0.195$ & $14.8 \%$ & $\$ 1.293$ & $\$ 1.102$ & $\$ 0.191$ & $14.8 \%$ & $\$ 1.286$ & $\$ 1.162$ & $\$ 0.124$ & $9.6 \%$ \\
\hline \multicolumn{13}{|l|}{ Small Hotel } \\
\hline Electricity & $\$ 1.138$ & $\$ 1.035$ & $\$ 0.103$ & $9.1 \%$ & $\$ 1.138$ & $\$ 1.032$ & $\$ 0.106$ & $9.3 \%$ & $\$ 1.152$ & $\$ 1.044$ & $\$ 0.109$ & $9.5 \%$ \\
\hline Gas & $\$ 0.184$ & $\$ 0.184$ & $\$ 0.000$ & $0.0 \%$ & $\$ 0.193$ & $\$ 0.193$ & $\$ 0.000$ & $0.0 \%$ & $\$ 0.205$ & $\$ 0.206$ & $\$ 0.000$ & $0.0 \%$ \\
\hline Totals & $\$ 1.322$ & $\$ 1.220$ & $\$ 0.102$ & $7.7 \%$ & $\$ 1.331$ & $\$ 1.225$ & $\$ 0.106$ & $8.0 \%$ & $\$ 1.357$ & $\$ 1.249$ & $\$ 0.108$ & $8.0 \%$ \\
\hline \multicolumn{13}{|c|}{ Mid-Rise Apartment } \\
\hline Electricity & $\$ 1.213$ & $\$ 1.169$ & $\$ 0.044$ & $3.6 \%$ & $\$ 1.216$ & $\$ 1.173$ & $\$ 0.044$ & $3.6 \%$ & $\$ 1.206$ & $\$ 1.167$ & $\$ 0.039$ & $3.2 \%$ \\
\hline Gas & $\$ 0.039$ & $\$ 0.034$ & $\$ 0.005$ & $12.8 \%$ & $\$ 0.049$ & $\$ 0.040$ & $\$ 0.009$ & $18.4 \%$ & $\$ 0.066$ & $\$ 0.051$ & $\$ 0.015$ & $22.7 \%$ \\
\hline Totals & $\$ 1.252$ & $\$ 1.203$ & $\$ 0.050$ & $4.0 \%$ & $\$ 1.265$ & $\$ 1.213$ & $\$ 0.052$ & $4.1 \%$ & $\$ 1.272$ & $\$ 1.218$ & $\$ 0.053$ & $4.2 \%$ \\
\hline
\end{tabular}


Table 10.B. Energy Cost Saving Results in Colorado, \$ per Square Foot

\begin{tabular}{|c|c|c|c|c|}
\hline \multirow{2}{*}{$\begin{array}{l}\text { Climate Zone: } \\
\text { Code: }\end{array}$} & \multicolumn{4}{|c|}{7} \\
\hline & $90.1-2010$ & $90.1-2013$ & Savings & \\
\hline \multicolumn{5}{|l|}{ Small Office } \\
\hline Electricity & $\$ 0.906$ & $\$ 0.831$ & $\$ 0.075$ & $8.3 \%$ \\
\hline Gas & $\$ 0.015$ & $\$ 0.013$ & $\$ 0.003$ & $20.0 \%$ \\
\hline Totals & $\$ 0.921$ & $\$ 0.844$ & $\$ 0.078$ & $8.5 \%$ \\
\hline \multicolumn{5}{|l|}{ Large Office } \\
\hline Electricity & $\$ 1.976$ & $\$ 1.951$ & $\$ 0.024$ & $1.2 \%$ \\
\hline Gas & $\$ 0.068$ & $\$ 0.068$ & $\$ 0.000$ & $0.0 \%$ \\
\hline Totals & $\$ 2.043$ & $\$ 2.019$ & $\$ 0.024$ & $1.2 \%$ \\
\hline \multicolumn{5}{|c|}{ Standalone Retail } \\
\hline Electricity & $\$ 1.148$ & $\$ 1.048$ & $\$ 0.100$ & $8.7 \%$ \\
\hline Gas & $\$ 0.168$ & $\$ 0.077$ & $\$ 0.091$ & $54.2 \%$ \\
\hline Totals & $\$ 1.316$ & $\$ 1.125$ & $\$ 0.191$ & $14.5 \%$ \\
\hline \multicolumn{5}{|c|}{ Primary School } \\
\hline Electricity & $\$ 1.118$ & $\$ 1.002$ & $\$ 0.116$ & $10.4 \%$ \\
\hline Gas & $\$ 0.169$ & $\$ 0.166$ & $\$ 0.003$ & $1.8 \%$ \\
\hline Totals & $\$ 1.287$ & $\$ 1.168$ & $\$ 0.120$ & $9.3 \%$ \\
\hline \multicolumn{5}{|l|}{ Small Hotel } \\
\hline Electricity & $\$ 1.147$ & $\$ 1.033$ & $\$ 0.115$ & $10.0 \%$ \\
\hline Gas & $\$ 0.215$ & $\$ 0.215$ & $\$ 0.000$ & $0.0 \%$ \\
\hline Totals & $\$ 1.363$ & $\$ 1.248$ & $\$ 0.115$ & $8.4 \%$ \\
\hline \multicolumn{5}{|c|}{ Mid-Rise Apartment } \\
\hline Electricity & $\$ 1.206$ & $\$ 1.187$ & $\$ 0.019$ & $1.6 \%$ \\
\hline Gas & $\$ 0.067$ & $\$ 0.052$ & $\$ 0.015$ & $22.4 \%$ \\
\hline Totals & $\$ 1.273$ & $\$ 1.239$ & $\$ 0.034$ & $2.7 \%$ \\
\hline
\end{tabular}


Table 11.A. Energy Use Saving Results in Colorado, Energy Use per Square Foot

\begin{tabular}{|c|c|c|c|c|c|c|c|c|c|c|c|c|}
\hline \multirow{2}{*}{$\begin{array}{l}\text { Climate Zone: } \\
\text { Code: }\end{array}$} & \multicolumn{4}{|c|}{$4 B$} & \multicolumn{4}{|c|}{$5 B$} & \multicolumn{4}{|c|}{$6 \mathrm{~B}$} \\
\hline & $90.1-2010$ & $90.1-2013$ & Savings & & $90.1-2010$ & $90.1-2013$ & Savings & & $90.1-2010$ & $90.1-2013$ & Savings & \\
\hline \multicolumn{13}{|l|}{ Small Office } \\
\hline Electricity, $\mathrm{kWh} / \mathrm{ft}^{2}$ & 9.415 & 8.438 & 0.976 & $10.4 \%$ & 9.179 & 8.313 & 0.866 & $9.4 \%$ & 8.986 & 8.226 & 0.760 & $8.5 \%$ \\
\hline Gas, therm $/ \mathrm{ft}^{2}$ & 0.006 & 0.004 & 0.001 & $16.7 \%$ & 0.005 & 0.004 & 0.001 & $20.0 \%$ & 0.013 & 0.012 & 0.002 & $15.4 \%$ \\
\hline Totals, kBtu/ft ${ }^{2}$ & 32.694 & 29.219 & 3.475 & $10.6 \%$ & 31.839 & 28.755 & 3.084 & $9.7 \%$ & 31.999 & 29.239 & 2.760 & $8.6 \%$ \\
\hline \multicolumn{13}{|l|}{ Large Office } \\
\hline Electricity, $\mathrm{kWh} / \mathrm{ft}^{2}$ & 19.907 & 19.345 & 0.562 & $2.8 \%$ & 19.547 & 19.077 & 0.470 & $2.4 \%$ & 19.403 & 19.039 & 0.364 & $1.9 \%$ \\
\hline Gas, therm/ $\mathrm{ft}^{2}$ & 0.049 & 0.042 & 0.008 & $16.3 \%$ & 0.055 & 0.047 & 0.009 & $16.4 \%$ & 0.078 & 0.084 & -0.007 & $-9.0 \%$ \\
\hline Totals, kBtu/ft ${ }^{2}$ & 72.851 & 70.176 & 2.675 & $3.7 \%$ & 72.242 & 69.780 & 2.462 & $3.4 \%$ & 74.003 & 73.419 & 0.584 & $0.8 \%$ \\
\hline \multicolumn{13}{|l|}{ Stand-Alone Retail } \\
\hline Electricity, $\mathrm{kWh} / \mathrm{ft}^{2}$ & 12.118 & 10.808 & 1.310 & $10.8 \%$ & 11.798 & 10.659 & 1.139 & $9.7 \%$ & 11.680 & 10.396 & 1.284 & $11.0 \%$ \\
\hline Gas, therm $/ \mathrm{ft}^{2}$ & 0.137 & 0.117 & 0.020 & $14.6 \%$ & 0.156 & 0.128 & 0.028 & $17.9 \%$ & 0.192 & 0.170 & 0.022 & $11.5 \%$ \\
\hline Totals, $\mathrm{kBtu} / \mathrm{ft}^{2}$ & 55.016 & 48.538 & 6.477 & $11.8 \%$ & 55.823 & 49.157 & 6.666 & $11.9 \%$ & 59.059 & 52.519 & 6.539 & $11.1 \%$ \\
\hline \multicolumn{13}{|l|}{ Primary School } \\
\hline Electricity, $\mathrm{kWh} / \mathrm{ft}^{2}$ & 11.863 & 9.690 & 2.173 & $18.3 \%$ & 11.530 & 9.352 & 2.178 & $18.9 \%$ & 11.201 & 10.058 & 1.143 & $10.2 \%$ \\
\hline Gas, therm/ $\mathrm{ft}^{2}$ & 0.140 & 0.173 & -0.033 & $-23.6 \%$ & 0.148 & 0.187 & -0.039 & $-26.4 \%$ & 0.181 & 0.172 & 0.009 & $5.0 \%$ \\
\hline Totals, kBtu/ft ${ }^{2}$ & 54.507 & 50.418 & 4.089 & $7.5 \%$ & 54.140 & 50.620 & 3.520 & $6.5 \%$ & 56.356 & 51.523 & 4.833 & $8.6 \%$ \\
\hline \multicolumn{13}{|l|}{ Small Hotel } \\
\hline Electricity, $\mathrm{kWh} / \mathrm{ft}^{2}$ & 11.158 & 10.149 & 1.009 & $9.0 \%$ & 11.159 & 10.117 & 1.042 & $9.3 \%$ & 11.294 & 10.231 & 1.064 & $9.4 \%$ \\
\hline Gas, therm $/ \mathrm{ft}^{2}$ & 0.233 & 0.234 & -0.001 & $-0.4 \%$ & 0.244 & 0.244 & 0.000 & $0.0 \%$ & 0.260 & 0.260 & -0.001 & $-0.4 \%$ \\
\hline Totals, $\mathrm{kBtu} / \mathrm{ft}^{2}$ & 61.381 & 57.994 & 3.386 & $5.5 \%$ & 62.463 & 58.950 & 3.513 & $5.6 \%$ & 64.517 & 60.943 & 3.574 & $5.5 \%$ \\
\hline \multicolumn{13}{|l|}{ Mid-Rise Apartment } \\
\hline Electricity, $\mathrm{kWh} / \mathrm{ft}^{2}$ & 11.896 & 11.460 & 0.435 & $3.7 \%$ & 11.924 & 11.497 & 0.427 & $3.6 \%$ & 11.822 & 11.443 & 0.379 & $3.2 \%$ \\
\hline Gas, therm $/ \mathrm{ft}^{2}$ & 0.049 & 0.043 & 0.007 & $14.3 \%$ & 0.062 & 0.051 & 0.011 & $17.7 \%$ & 0.083 & 0.065 & 0.019 & $22.9 \%$ \\
\hline Totals, kBtu/ft ${ }^{2}$ & 45.534 & 43.379 & 2.155 & $4.7 \%$ & 46.850 & 44.290 & 2.560 & $5.5 \%$ & 48.686 & 45.534 & 3.153 & $6.5 \%$ \\
\hline
\end{tabular}


Table 11.B. Energy Use Saving Results in Colorado, Energy Use per Square Foot

\begin{tabular}{|c|c|c|c|c|}
\hline \multirow{2}{*}{$\begin{array}{l}\text { Climate Zone: } \\
\text { Code: }\end{array}$} & \multicolumn{4}{|c|}{7} \\
\hline & $90.1-2010$ & $90.1-2013$ & Savings & \\
\hline \multicolumn{5}{|l|}{ Small Office } \\
\hline Electricity, $\mathrm{kWh} / \mathrm{ft}^{2}$ & 8.881 & 8.145 & 0.736 & $8.3 \%$ \\
\hline Gas, therm $/ \mathrm{ft}^{2}$ & 0.020 & 0.016 & 0.003 & $15.0 \%$ \\
\hline Totals, kBtu/ft ${ }^{2}$ & 32.268 & 29.415 & 2.853 & $8.8 \%$ \\
\hline \multicolumn{5}{|l|}{ Large Office } \\
\hline Electricity, $\mathrm{kWh} / \mathrm{ft}^{2}$ & 19.368 & 19.128 & 0.240 & $1.2 \%$ \\
\hline Gas, therm/ $\mathrm{ft}^{2}$ & 0.086 & 0.086 & -0.001 & $-1.2 \%$ \\
\hline Totals, kBtu/ft ${ }^{2}$ & 74.666 & 73.897 & 0.769 & $1.0 \%$ \\
\hline \multicolumn{5}{|l|}{ Standalone Retail } \\
\hline Electricity, $\mathrm{kWh} / \mathrm{ft}^{2}$ & 11.255 & 10.277 & 0.978 & $8.7 \%$ \\
\hline Gas, therm $/ \mathrm{ft}^{2}$ & 0.213 & 0.097 & 0.116 & $54.5 \%$ \\
\hline Totals, kBtu/ft ${ }^{2}$ & 59.681 & 44.777 & 14.903 & $25.0 \%$ \\
\hline \multicolumn{5}{|l|}{ Primary School } \\
\hline Electricity, $\mathrm{kWh} / \mathrm{ft}^{2}$ & 10.961 & 9.821 & 1.140 & $10.4 \%$ \\
\hline Gas, therm $/ \mathrm{ft}^{2}$ & 0.214 & 0.210 & 0.004 & $1.9 \%$ \\
\hline Totals, kBtu/ft ${ }^{2}$ & 58.851 & 54.538 & 4.312 & $7.3 \%$ \\
\hline \multicolumn{5}{|l|}{ Small Hotel } \\
\hline Electricity, $\mathrm{kWh} / \mathrm{ft}^{2}$ & 11.248 & 10.123 & 1.124 & $10.0 \%$ \\
\hline Gas, therm $/ \mathrm{ft}^{2}$ & 0.273 & 0.273 & 0.000 & $0.0 \%$ \\
\hline Totals, kBtu/ft ${ }^{2}$ & 65.653 & 61.824 & 3.829 & $5.8 \%$ \\
\hline \multicolumn{5}{|l|}{ Mid-Rise Apartment } \\
\hline Electricity, $\mathrm{kWh} / \mathrm{ft}^{2}$ & 11.821 & 11.633 & 0.188 & $1.6 \%$ \\
\hline Gas, therm $/ \mathrm{ft}^{2}$ & 0.085 & 0.066 & 0.018 & $21.2 \%$ \\
\hline Totals, kBtu/ft ${ }^{2}$ & 48.802 & 46.316 & 2.485 & $5.1 \%$ \\
\hline
\end{tabular}


Table 12.A. Annual Energy Usage for Buildings in Colorado in Climate Zone 4B

\begin{tabular}{|c|c|c|c|c|c|c|c|c|c|c|c|c|}
\hline \multirow{2}{*}{$\begin{array}{c}\text { Energy } \\
\text { End-Use }\end{array}$} & \multicolumn{2}{|c|}{ Small Office } & \multicolumn{2}{|c|}{ Large Office } & \multicolumn{2}{|c|}{ Stand-Alone Retail } & \multicolumn{2}{|c|}{ Primary School } & \multicolumn{2}{|c|}{ Small Hotel } & \multicolumn{2}{|c|}{ Mid-Rise Apartment } \\
\hline & $\begin{array}{l}\text { Electric } \\
\mathrm{kWh} / \\
\mathrm{ft}^{2} \cdot \mathrm{yr}\end{array}$ & $\begin{array}{c}\text { Gas } \\
\text { therms/ } \\
\mathrm{ft}^{2} \cdot \mathrm{yr}\end{array}$ & $\begin{array}{l}\text { Electric } \\
\mathrm{kWh} / \\
\mathrm{ft}^{2} \cdot \mathrm{yr}\end{array}$ & $\begin{array}{c}\text { Gas } \\
\text { therms/ } \\
\mathrm{ft}^{2} \cdot \mathrm{yr}\end{array}$ & $\begin{array}{l}\text { Electric } \\
\mathrm{kWh} / \\
\mathrm{ft}^{2} \cdot \mathrm{yr}\end{array}$ & $\begin{array}{c}\text { Gas } \\
\text { therms/ } \\
\mathrm{ft}^{2} \cdot \mathrm{yr}\end{array}$ & $\begin{array}{l}\text { Electric } \\
\mathrm{kWh} / \\
\mathrm{ft}^{2} \cdot \mathrm{yr}\end{array}$ & $\begin{array}{c}\text { Gas } \\
\text { therms/ } \\
\mathrm{ft}^{2} \cdot \mathrm{yr}\end{array}$ & $\begin{array}{l}\text { Electric } \\
\mathrm{kWh} / \\
\mathrm{ft}^{2} \cdot \mathrm{yr}\end{array}$ & $\begin{array}{c}\text { Gas } \\
\text { therms/ } \\
\mathrm{ft}^{2} \cdot \mathrm{yr}\end{array}$ & $\begin{array}{l}\text { Electric } \\
\mathrm{kWh} / \\
\mathrm{ft}^{2} \cdot \mathrm{yr}\end{array}$ & $\begin{array}{c}\text { Gas } \\
\text { therms/ } \\
\mathrm{ft}^{2} \cdot \mathrm{yr}\end{array}$ \\
\hline \multicolumn{13}{|l|}{ ASHRAE 90.1-2010 } \\
\hline Heating, Humidification & 0.336 & 0.006 & 1.428 & 0.039 & 0.000 & 0.101 & 0.000 & 0.079 & 0.832 & 0.011 & 0.000 & 0.049 \\
\hline Cooling & 1.025 & 0.000 & 1.734 & 0.000 & 1.324 & 0.000 & 1.604 & 0.000 & 1.579 & 0.000 & 1.018 & 0.000 \\
\hline Fans, Pumps, Heat Recovery & 1.348 & 0.000 & 1.853 & 0.000 & 2.862 & 0.000 & 1.864 & 0.000 & 1.884 & 0.000 & 2.026 & 0.000 \\
\hline Lighting, Interior \& Exterior & 3.311 & 0.000 & 2.490 & 0.000 & 5.742 & 0.000 & 3.152 & 0.000 & 3.064 & 0.000 & 1.438 & 0.000 \\
\hline Plugs, Refrigeration, Other & 2.485 & 0.000 & 12.401 & 0.000 & 2.190 & 0.000 & 5.146 & 0.046 & 3.799 & 0.092 & 4.210 & 0.000 \\
\hline Service Water Heating (SWH) & 0.910 & 0.000 & 0.000 & 0.010 & 0.000 & 0.036 & 0.097 & 0.015 & 0.000 & 0.129 & 3.203 & 0.000 \\
\hline Total & 9.415 & 0.006 & 19.907 & 0.049 & 12.118 & 0.137 & 11.863 & 0.140 & 11.158 & 0.233 & 11.896 & 0.049 \\
\hline \multicolumn{13}{|l|}{ ASHRAE 90.1-2013 } \\
\hline Heating, Humidification & 0.268 & 0.004 & 1.349 & 0.031 & 0.000 & 0.081 & 0.000 & 0.112 & 0.869 & 0.012 & 0.000 & 0.043 \\
\hline Cooling & 0.742 & 0.000 & 1.571 & 0.000 & 1.166 & 0.000 & 1.216 & 0.000 & 1.346 & 0.000 & 0.867 & 0.000 \\
\hline Fans, Pumps, Heat Recovery & 1.174 & 0.000 & 1.760 & 0.000 & 2.520 & 0.000 & 0.977 & 0.000 & 1.867 & 0.000 & 1.944 & 0.000 \\
\hline Lighting, Interior \& Exterior & 2.906 & 0.000 & 2.277 & 0.000 & 4.936 & 0.000 & 2.780 & 0.000 & 2.481 & 0.000 & 1.242 & 0.000 \\
\hline Plugs, Refrigeration, Other & 2.439 & 0.000 & 12.388 & 0.000 & 2.186 & 0.000 & 4.620 & 0.046 & 3.585 & 0.092 & 4.208 & 0.000 \\
\hline Service Water Heating (SWH) & 0.910 & 0.000 & 0.000 & 0.010 & 0.000 & 0.036 & 0.097 & 0.015 & 0.000 & 0.129 & 3.200 & 0.000 \\
\hline Total & 8.438 & 0.004 & 19.345 & 0.042 & 10.808 & 0.117 & 9.690 & 0.173 & 10.149 & 0.234 & 11.460 & 0.043 \\
\hline Total Savings & 0.976 & 0.001 & 0.562 & 0.008 & 1.310 & 0.020 & 2.173 & -0.033 & 1.009 & -0.001 & 0.435 & 0.007 \\
\hline
\end{tabular}


Table 12.B. Annual Energy Usage for Buildings in Colorado in Climate Zone 5B

\begin{tabular}{|c|c|c|c|c|c|c|c|c|c|c|c|c|}
\hline \multirow{2}{*}{$\begin{array}{c}\text { Energy } \\
\text { End-Use }\end{array}$} & \multicolumn{2}{|c|}{ Small Office } & \multicolumn{2}{|c|}{ Large Office } & \multicolumn{2}{|c|}{ Stand-Alone Retail } & \multicolumn{2}{|c|}{ Primary School } & \multicolumn{2}{|c|}{ Small Hotel } & \multicolumn{2}{|c|}{ Mid-Rise Apartment } \\
\hline & $\begin{array}{l}\text { Electric } \\
\mathrm{kWh} / \\
\mathrm{ft}^{2} \cdot \mathrm{yr}\end{array}$ & $\begin{array}{c}\text { Gas } \\
\text { therms/ } \\
\mathrm{ft}^{2} \cdot \mathrm{yr}\end{array}$ & $\begin{array}{l}\text { Electric } \\
\mathrm{kWh} / \\
\mathrm{ft}^{2} \cdot \mathrm{yr}\end{array}$ & $\begin{array}{c}\text { Gas } \\
\text { therms/ } \\
\mathrm{ft}^{2} \cdot \mathrm{yr}\end{array}$ & $\begin{array}{l}\text { Electric } \\
\mathrm{kWh} / \\
\mathrm{ft}^{2} \cdot \mathrm{yr}\end{array}$ & $\begin{array}{c}\text { Gas } \\
\text { therms/ } \\
\mathrm{ft}^{2} \cdot \mathrm{yr}\end{array}$ & $\begin{array}{l}\text { Electric } \\
\mathrm{kWh} / \\
\mathrm{ft}^{2} \cdot \mathrm{yr}\end{array}$ & $\begin{array}{c}\text { Gas } \\
\text { therms/ } \\
\mathrm{ft}^{2} \cdot \mathrm{yr}\end{array}$ & $\begin{array}{l}\text { Electric } \\
\mathrm{kWh} / \\
\mathrm{ft}^{2} \cdot \mathrm{yr}\end{array}$ & $\begin{array}{c}\text { Gas } \\
\text { therms/ } \\
\mathrm{ft}^{2} \cdot \mathrm{yr}\end{array}$ & $\begin{array}{l}\text { Electric } \\
\mathrm{kWh} / \\
\mathrm{ft}^{2} \cdot \mathrm{yr}\end{array}$ & $\begin{array}{c}\text { Gas } \\
\text { therms/ } \\
\mathrm{ft}^{2} \cdot \mathrm{yr}\end{array}$ \\
\hline \multicolumn{13}{|l|}{ ASHRAE 90.1-2010 } \\
\hline Heating, Humidification & 0.372 & 0.005 & 1.439 & 0.045 & 0.000 & 0.119 & 0.000 & 0.086 & 0.996 & 0.013 & 0.000 & 0.062 \\
\hline Cooling & 0.820 & 0.000 & 1.397 & 0.000 & 1.020 & 0.000 & 1.307 & 0.000 & 1.413 & 0.000 & 0.863 & 0.000 \\
\hline Fans, Pumps, Heat Recovery & 1.284 & 0.000 & 1.820 & 0.000 & 2.839 & 0.000 & 1.831 & 0.000 & 1.887 & 0.000 & 2.016 & 0.000 \\
\hline Lighting, Interior \& Exterior & 3.309 & 0.000 & 2.490 & 0.000 & 5.750 & 0.000 & 3.149 & 0.000 & 3.064 & 0.000 & 1.438 & 0.000 \\
\hline Plugs, Refrigeration, Other & 2.485 & 0.000 & 12.401 & 0.000 & 2.190 & 0.000 & 5.146 & 0.046 & 3.799 & 0.092 & 4.210 & 0.000 \\
\hline Service Water Heating (SWH) & 0.910 & 0.000 & 0.000 & 0.011 & 0.000 & 0.037 & 0.097 & 0.016 & 0.000 & 0.138 & 3.396 & 0.000 \\
\hline Total & 9.179 & & 19.547 & 0.055 & 11.798 & 0.156 & 11.530 & 0.148 & 11.159 & 0.244 & 11.924 & 0.062 \\
\hline \multicolumn{13}{|l|}{ ASHRAE 90.1-2013 } \\
\hline Heating, Humidification & 0.306 & & 1.361 & 0.036 & 0.000 & 0.091 & 0.000 & 0.125 & 0.990 & 0.014 & 0.000 & 0.051 \\
\hline Cooling & 0.611 & 0.000 & 1.275 & 0.000 & 0.895 & 0.000 & 0.922 & 0.000 & 1.195 & 0.000 & 0.739 & 0.000 \\
\hline Fans, Pumps, Heat Recovery & 1.145 & 0.000 & 1.777 & 0.000 & 2.644 & 0.000 & 0.940 & 0.000 & 1.868 & 0.000 & 1.915 & 0.000 \\
\hline Lighting, Interior \& Exterior & 2.902 & 0.000 & 2.276 & 0.000 & 4.934 & 0.000 & 2.773 & 0.000 & 2.479 & 0.000 & 1.241 & 0.000 \\
\hline Plugs, Refrigeration, Other & 2.439 & 0.000 & 12.388 & 0.000 & 2.186 & 0.000 & 4.620 & 0.046 & 3.585 & 0.092 & 4.208 & 0.000 \\
\hline Service Water Heating (SWH) & 0.910 & 0.000 & 0.000 & 0.011 & 0.000 & 0.037 & 0.097 & 0.016 & 0.000 & 0.138 & 3.394 & 0.000 \\
\hline Total & 8.313 & & 19.077 & 0.047 & 10.659 & 0.128 & 9.352 & 0.187 & 10.117 & 0.244 & 11.497 & 0.051 \\
\hline Total Savings & 0.866 & 0.001 & 0.470 & 0.009 & 1.139 & 0.028 & 2.178 & -0.039 & 1.042 & 0.000 & 0.427 & 0.011 \\
\hline
\end{tabular}


Table 12.C. Annual Energy Usage for Buildings in Colorado in Climate Zone 6B

\begin{tabular}{|c|c|c|c|c|c|c|c|c|c|c|c|c|}
\hline \multirow{2}{*}{$\begin{array}{l}\text { Energy } \\
\text { End-Use }\end{array}$} & \multicolumn{2}{|c|}{ Small Office } & \multicolumn{2}{|c|}{ Large Office } & \multicolumn{2}{|c|}{ Stand-Alone Retail } & \multicolumn{2}{|c|}{ Primary School } & \multicolumn{2}{|c|}{ Small Hotel } & \multicolumn{2}{|c|}{ Mid-Rise Apartment } \\
\hline & $\begin{array}{c}\text { Electric } \\
\mathrm{kWh} / \\
\mathrm{ft}^{2} \cdot \mathrm{yr}\end{array}$ & $\begin{array}{c}\text { Gas } \\
\text { therms/ } \\
\mathrm{ft}^{2} \cdot \mathrm{yr}\end{array}$ & $\begin{array}{l}\text { Electric } \\
\mathrm{kWh} / \\
\mathrm{ft}^{2} \cdot \mathrm{yr}\end{array}$ & $\begin{array}{c}\text { Gas } \\
\text { therms/ } \\
\mathrm{ft}^{2} \cdot \mathrm{yr}\end{array}$ & $\begin{array}{l}\text { Electric } \\
\mathrm{kWh} / \\
\mathrm{ft}^{2} \cdot \mathrm{yr}\end{array}$ & $\begin{array}{c}\text { Gas } \\
\text { therms/ } \\
\mathrm{ft}^{2} \cdot \mathrm{yr}\end{array}$ & $\begin{array}{c}\text { Electric } \\
\mathrm{kWh} / \\
\mathrm{ft}^{2} \cdot \mathrm{yr}\end{array}$ & $\begin{array}{c}\text { Gas } \\
\text { therms/ } \\
\mathrm{ft}^{2} \cdot \mathrm{yr}\end{array}$ & $\begin{array}{c}\text { Electric } \\
\mathrm{kWh} / \\
\mathrm{ft}^{2} \cdot \mathrm{yr}\end{array}$ & $\begin{array}{c}\text { Gas } \\
\text { therms/ } \\
\mathrm{ft}^{2} \cdot \mathrm{yr}\end{array}$ & $\begin{array}{c}\text { Electric } \\
\mathrm{kWh} / \\
\mathrm{ft}^{2} \cdot \mathrm{yr}\end{array}$ & $\begin{array}{c}\text { Gas } \\
\text { therms/ } \\
\mathrm{ft}^{2} \cdot \mathrm{yr}\end{array}$ \\
\hline \multicolumn{13}{|l|}{ ASHRAE 90.1-2010 } \\
\hline Heating, Humidification & 0.434 & 0.013 & 1.618 & 0.066 & 0.000 & 0.154 & 0.000 & 0.118 & 1.414 & 0.019 & 0.000 & 0.083 \\
\hline Cooling & 0.634 & 0.000 & 1.117 & 0.000 & 0.752 & 0.000 & 0.923 & 0.000 & 1.137 & 0.000 & 0.667 & 0.000 \\
\hline Fans, Pumps, Heat Recovery & 1.216 & 0.000 & 1.778 & 0.000 & 2.769 & 0.000 & 1.889 & 0.000 & 1.880 & 0.000 & 1.887 & 0.000 \\
\hline Lighting, Interior \& Exterior & 3.308 & 0.000 & 2.489 & 0.000 & 5.969 & 0.000 & 3.148 & 0.000 & 3.063 & 0.000 & 1.438 & 0.000 \\
\hline Plugs, Refrigeration, Other & 2.485 & 0.000 & 12.401 & 0.000 & 2.190 & 0.000 & 5.144 & 0.046 & 3.799 & 0.092 & 4.210 & 0.000 \\
\hline Service Water Heating (SWH) & 0.910 & 0.000 & 0.000 & 0.012 & 0.000 & 0.038 & 0.097 & 0.017 & 0.000 & 0.148 & 3.620 & 0.000 \\
\hline Total & 8.986 & 0.013 & 19.403 & 0.078 & 11.680 & 0.192 & 11.201 & 0.181 & 11.294 & 0.260 & 11.822 & 0.083 \\
\hline \multicolumn{13}{|l|}{ ASHRAE 90.1-2013 } \\
\hline Heating, Humidification & 0.395 & 0.012 & 1.561 & 0.073 & 0.000 & 0.133 & 0.000 & 0.109 & 1.344 & 0.019 & 0.000 & 0.065 \\
\hline Cooling & 0.467 & 0.000 & 1.039 & 0.000 & 0.668 & 0.000 & 0.812 & 0.000 & 0.962 & 0.000 & 0.585 & 0.000 \\
\hline Fans, Pumps, Heat Recovery & 1.113 & 0.000 & 1.776 & 0.000 & 2.330 & 0.000 & 1.761 & 0.000 & 1.863 & 0.000 & 1.793 & 0.000 \\
\hline Lighting, Interior \& Exterior & 2.903 & 0.000 & 2.275 & 0.000 & 5.212 & 0.000 & 2.770 & 0.000 & 2.478 & 0.000 & 1.242 & 0.000 \\
\hline Plugs, Refrigeration, Other & 2.439 & 0.000 & 12.388 & 0.000 & 2.186 & 0.000 & 4.618 & 0.046 & 3.585 & 0.092 & 4.208 & 0.000 \\
\hline Service Water Heating (SWH) & 0.910 & 0.000 & 0.000 & 0.012 & 0.000 & 0.038 & 0.097 & 0.017 & 0.000 & 0.148 & 3.617 & 0.000 \\
\hline Total & 8.226 & 0.012 & 19.039 & 0.084 & 10.396 & 0.170 & 10.058 & 0.172 & 10.231 & 0.260 & 11.443 & 0.065 \\
\hline Total Savings & 0.760 & 0.002 & 0.364 & -0.007 & 1.284 & 0.022 & 1.143 & 0.009 & 1.064 & -0.001 & 0.379 & 0.019 \\
\hline
\end{tabular}


Table 12.D. Annual Energy Usage for Buildings in Colorado in Climate Zone 7

\begin{tabular}{|c|c|c|c|c|c|c|c|c|c|c|c|c|}
\hline \multirow{2}{*}{$\begin{array}{c}\text { Energy } \\
\text { End-Use }\end{array}$} & \multicolumn{2}{|c|}{ Small Office } & \multicolumn{2}{|c|}{ Large Office } & \multicolumn{2}{|c|}{ Stand-Alone Retail } & \multicolumn{2}{|c|}{ Primary School } & \multicolumn{2}{|c|}{ Small Hotel } & \multicolumn{2}{|c|}{ Mid-Rise Apartment } \\
\hline & $\begin{array}{c}\text { Electric } \\
\mathrm{kWh} / \\
\mathrm{ft}^{2} \cdot \mathrm{yr}\end{array}$ & $\begin{array}{c}\text { Gas } \\
\text { therms/ } \\
\mathrm{ft}^{2} \cdot y \mathrm{r}\end{array}$ & $\begin{array}{l}\text { Electric } \\
\mathrm{kWh} / \\
\mathrm{ft}^{2} \cdot \mathrm{yr}\end{array}$ & $\begin{array}{c}\text { Gas } \\
\text { therms/ } \\
\mathrm{ft}^{2} \cdot \mathrm{yr}\end{array}$ & $\begin{array}{l}\text { Electric } \\
\mathrm{kWh} / \\
\mathrm{ft}^{2} \cdot \mathrm{yr}\end{array}$ & $\begin{array}{c}\text { Gas } \\
\text { therms/ } \\
\mathrm{ft}^{2} \cdot \mathrm{yr}\end{array}$ & $\begin{array}{l}\text { Electric } \\
\mathrm{kWh} / \\
\mathrm{ft}^{2} \cdot \mathrm{yr}\end{array}$ & $\begin{array}{c}\text { Gas } \\
\text { therms/ } \\
\mathrm{ft}^{2} \cdot \mathrm{yr}\end{array}$ & $\begin{array}{l}\text { Electric } \\
\mathrm{kWh} / \\
\mathrm{ft}^{2} \cdot \mathrm{yr}\end{array}$ & $\begin{array}{c}\text { Gas } \\
\text { therms/ } \\
\mathrm{ft}^{2} \cdot \mathrm{yr}\end{array}$ & $\begin{array}{l}\text { Electric } \\
\mathrm{kWh} / \\
\mathrm{ft}^{2} \cdot \mathrm{yr}\end{array}$ & $\begin{array}{c}\text { Gas } \\
\text { therms/ } \\
\mathrm{ft}^{2} \cdot \mathrm{yr}\end{array}$ \\
\hline \multicolumn{13}{|l|}{ ASHRAE 90.1-2010 } \\
\hline Heating, Humidification & 0.465 & 0.020 & 1.743 & 0.073 & 0.000 & 0.174 & 0.000 & 0.150 & 1.462 & 0.021 & 0.000 & 0.085 \\
\hline Cooling & 0.524 & 0.000 & 0.900 & 0.000 & 0.501 & 0.000 & 0.698 & 0.000 & 1.034 & 0.000 & 0.570 & 0.000 \\
\hline Fans, Pumps, Heat Recovery & 1.187 & 0.000 & 1.833 & 0.000 & 2.756 & 0.000 & 1.885 & 0.000 & 1.891 & 0.000 & 1.747 & 0.000 \\
\hline Lighting, Interior \& Exterior & 3.311 & 0.000 & 2.490 & 0.000 & 5.809 & 0.000 & 3.136 & 0.000 & 3.062 & 0.000 & 1.439 & 0.000 \\
\hline Plugs, Refrigeration, Other & 2.484 & 0.000 & 12.401 & 0.000 & 2.190 & 0.000 & 5.145 & 0.046 & 3.799 & 0.092 & 4.210 & 0.000 \\
\hline Service Water Heating (SWH) & 0.910 & 0.000 & 0.000 & 0.012 & 0.000 & 0.039 & 0.097 & 0.018 & 0.000 & 0.159 & 3.856 & 0.000 \\
\hline Total & 8.881 & 0.020 & 19.368 & 0.086 & 11.255 & 0.213 & 10.961 & 0.214 & 11.248 & 0.273 & 11.821 & 0.085 \\
\hline \multicolumn{13}{|l|}{ ASHRAE 90.1-2013 } \\
\hline Heating, Humidification & 0.409 & 0.016 & 1.701 & 0.074 & 0.000 & 0.058 & 0.000 & 0.146 & 1.329 & 0.021 & 0.000 & 0.066 \\
\hline Cooling & 0.415 & 0.000 & 0.867 & 0.000 & 0.505 & 0.000 & 0.632 & 0.000 & 0.888 & 0.000 & 0.555 & 0.000 \\
\hline Fans, Pumps, Heat Recovery & 1.115 & 0.000 & 1.900 & 0.000 & 2.359 & 0.000 & 1.791 & 0.000 & 1.867 & 0.000 & 1.776 & 0.000 \\
\hline Lighting, Interior \& Exterior & 2.859 & 0.000 & 2.273 & 0.000 & 5.227 & 0.000 & 2.680 & 0.000 & 2.455 & 0.000 & 1.242 & 0.000 \\
\hline Plugs, Refrigeration, Other & 2.439 & 0.000 & 12.388 & 0.000 & 2.186 & 0.000 & 4.620 & 0.046 & 3.585 & 0.092 & 4.208 & 0.000 \\
\hline Service Water Heating (SWH) & 0.910 & 0.000 & 0.000 & 0.012 & 0.000 & 0.039 & 0.097 & 0.018 & 0.000 & 0.159 & 3.852 & 0.000 \\
\hline Total & 8.145 & 0.016 & 19.128 & 0.086 & 10.277 & 0.097 & 9.821 & 0.210 & 10.123 & 0.273 & 11.633 & 0.066 \\
\hline Total Savings & 0.736 & 0.003 & 0.240 & -0.001 & 0.978 & 0.116 & 1.140 & 0.004 & 1.124 & 0.000 & 0.188 & 0.018 \\
\hline
\end{tabular}




\section{References}

(ASHRAE) ANSI/ASHRAE/IES - American National Standards Institute, American Society of Heating, Refrigerating and Air-Conditioning Engineers, and Illuminating Engineering Society. 2010. ANSI/ASHRAE/IES 90.1-2010, Energy Standard for Buildings Except Low-Rise Residential Buildings. American Society of Heating, Refrigerating and Air-Conditioning Engineers, Atlanta, Georgia.

(ASHRAE) ANSI/ASHRAE/IES - American National Standards Institute, American Society of Heating, Refrigerating and Air-Conditioning Engineers, and Illuminating Engineering Society. 2013. ANSI/ASHRAE/IES 90.1-2013, Energy Standard for Buildings Except Low-Rise Residential Buildings. American Society of Heating, Refrigerating and Air-Conditioning Engineers, Atlanta, Georgia.

Bureau of Labor Statistics. 2015. "Producer Price Indexes, Table 6." Washington, D.C. Accessed April 28, 2015 at www.bls.gov/ppi/tables.htm.

Commercial Loan Direct. 2015. "Commercial Mortgage Interest Rates - Nationwide Lending, Mid Balance - Investor/Owner Occupied." Atlanta, Georgia. Accessed April 28, 2015 at www.commercialloandirect.com/commercial-rates.php.

(DOE) United States Department of Energy. 2012. "Residential IECC Cost Effectiveness Analysis and Results." U.S. Department of Energy, Washington, D.C. Accessed April 4, 2013 at www.energycodes.gov/development/residential/iecc_analysis.

(EIA) United States Energy Information Administration. 2015a. Electricity Power Monthly, February 2015. Energy Information Administration, Washington, D.C. Accessed March 27, 2015 at http://www.eia.gov/electricity/monthly/pdf/epm.pdf.

(EIA) United States Energy Information Administration. 2015b. Natural Gas Monthly, February 2015. Energy Information Administration, Washington, D.C. Accessed March 27, 2015 at http://www.eia.gov/naturalgas/monthly/pdf/ngm_all.pdf.

(FTA) Federation of Tax Administrators. 2015. "Range of State Corporate Income Tax Rates." Washington, D.C. Accessed March 17, 2015 at www.taxadmin.org/Fta/rate/corp_inc.pdf.

Fuller, S.K., and S.R. Petersen. 1995. Life-Cycle Costing Manual for the Federal Energy Management Program, NIST Handbook 135. U.S. Department of Commerce, Washington, D.C.

Halverson, M.A., R.A. Athalye, M.I. Rosenberg, Y.L. Xie, W. Wang, P.R. Hart, J. Zhang, S. Goel, and V.V. Mendon. 2014. ANSI/ASHRAE/IES Standard 90.1-2013 Determination of Energy Savings: Quantitative Analysis. PNNL-23479. Pacific Northwest National Laboratory, Richland, WA. http://www.pnnl.gov/main/publications/external/technical_reports/PNNL-23479.pdf

Hart, P.R., R.A. Athalye, M.A. Halverson, S.A. Loper, M.I. Rosenberg, Y.L. Xie, and E.E. Richman. 2015. National Cost-effectiveness of ANSI/ASHRAE/IES Standard 90.1-2013. PNNL-23824. Pacific Northwest National Laboratory, Richland, WA.

https://www.energycodes.gov/sites/default/files/documents/Cost-

effectiveness_of_ASHRAE_Standard_90-1-2013-Report.pdf

Jarnagin, R.E., and G.K. Bandyopadhyay. 2010. Weighting Factors for the Commercial Building Prototypes Used in the Development of ANSI/ASHRAE/IESNA 90.1-2010. PNNL-19116. Pacific Northwest National Laboratory, Richland, Washington. 
McGraw Hill Construction. 2007. McGraw Hill Construction Database (2003-2007). McGraw Hill Construction, New York, New York (available for purchase at http://dodge.construction.com/).

RS Means. 2012a. RSMeans Mechanical Cost Data, 35th Ed. Construction Publishers \& Consultants. Norwell, Massachusetts.

RS Means. 2012b. RSMeans Electrical Cost Data, 35th Ed. Construction Publishers \& Consultants. Norwell, Massachusetts.

RS Means. 2012c. RSMeans Construction Cost Data, 70th Ed. Construction Publishers \& Consultants. Norwell, Massachusetts.

RS Means. 2014a. RSMeans Mechanical Cost Data, 37th Ed. Construction Publishers \& Consultants. Norwell, Massachusetts.

RS Means. 2014b. RSMeans Electrical Cost Data, 37th Ed. Construction Publishers \& Consultants. Norwell, Massachusetts.

RS Means. 2014c. RSMeans Construction Cost Data, 72nd Ed. Construction Publishers \& Consultants. Norwell, Massachusetts.

Rushing, A.S., J.D. Kneifel, and B.C. Lippiatt. 2014. Energy Price Indices and Discount Factors for LifeCycle Cost Analysis - 2014. NISTIR 85-3273-29, National Institute of Standards and Technology, Gaithersburg, Maryland.

Tax Foundation. 2015. "State and Local Sales Tax Rates in 2014." Washington, D.C. Accessed March 17, 2015 at http://taxfoundation.org/article/state-and-local-sales-tax-rates-2014.

Watts, R. 2015. "RealtyRates.com Investor Survey - $1^{\text {st }}$ Quarter 2015 Permanent Financing." Palma Sola, Florida. Accessed April 28, 2015 at www.realtyrates.com/commercial-mortgage-rates.html.

The U.S. Department of Energy (DOE) provides estimates of energy and cost savings from code adoption at the National, Climate Zone, and State levels. For more information on how these estimates were developed, visit the DOE Building Energy Codes website: www.energycodes.gov/development/commercial

U.S. Department of Energy

Energy Efficiency and Renewable Energy BUILDING TECHNOLOGIES OFFICE
EERE Information Center www.energy.gov/eere
Building Energy Codes

For information on Building Energy

Codes, visit

http://www.energycodes.gov/ 



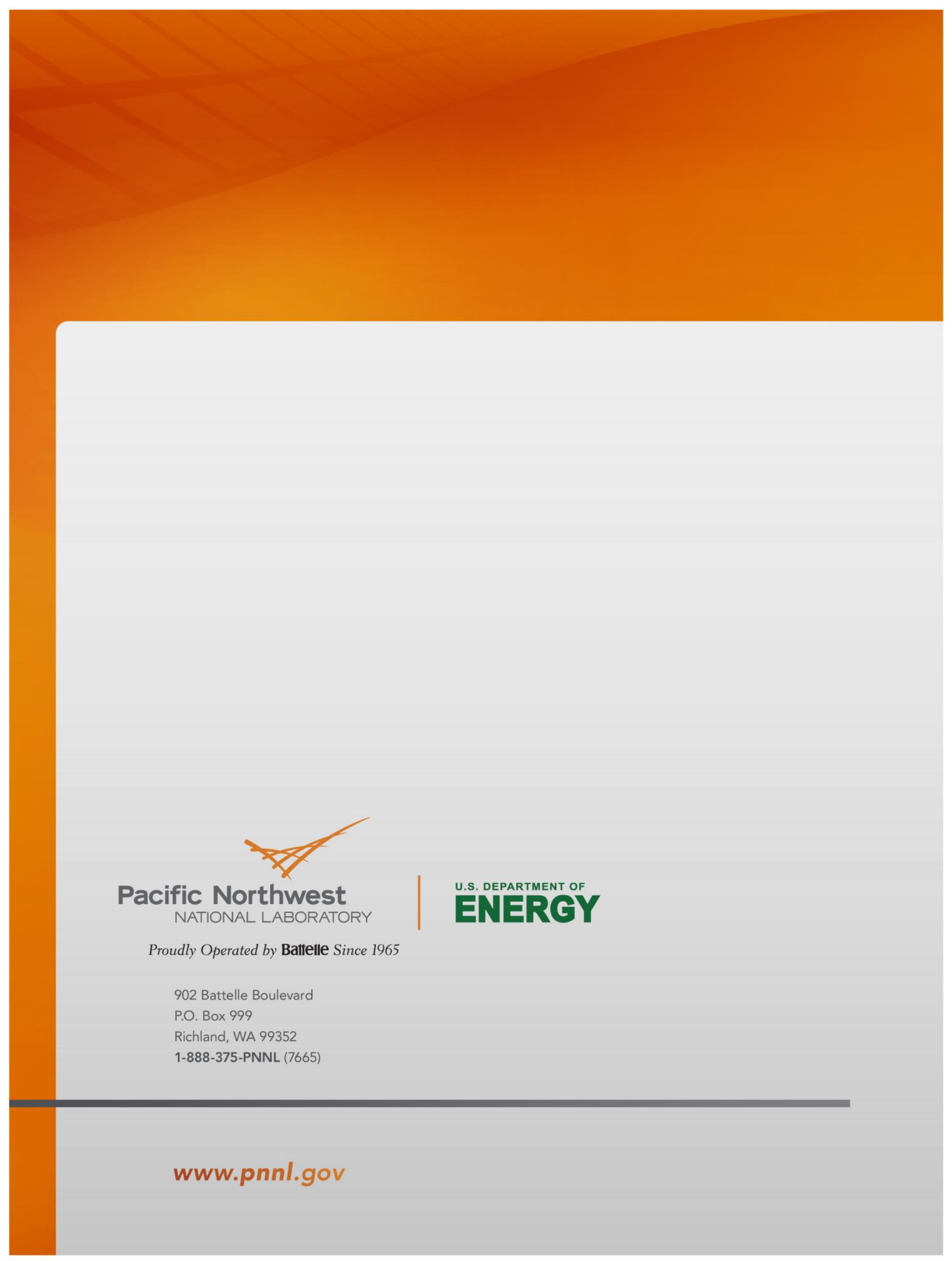

